\title{
EFFECTS OF COBALT ON THE HOT WORKABILITY
}

OF NICKEL-BASE SUPERALLOYS

\author{
Robert N. Jarrett, John P. Co11ier and John K. Tien \\ Center for Strategic Materials \\ Henry Krumb Schoool of Mines \\ Columbia University \\ New York, NY 10027
}

\begin{abstract}
Summary
It is found that reducing the cobalt content in representative wrought nicke1-base supera11 oys can result in an increase in both the $\gamma^{\prime}$ solvus temperature and the solvus temperature of carbides which precipitate as continuous and brittle intergranular networks. It is further found that these solvus temperatures border the hot working temperature range for the alloy. The standard working range for the alloy with $14 \%$ cobalt is between these two phase boundaries. However, removing the cobalt raises the transition temperatures so the standard working range now 1 ies below the carbide solvus. It is shown that the resulting stringers of carbide can either hamper heat treatment and diminish mechanical properties (in low carbon alloys) or eliminate workability altogether (in alloys containing more carbon). Thermomechanical processing modifications reflecting the effect of cobalt on the $\gamma^{\prime}$ and carbide solvi are shown to restore the workability and the properties of 10 and no cobalt alloys. The results of this study refute the often accepted wisdom that the strategic element cobalt is necessary for hot workability and for properties.
\end{abstract}




\section{Introduction}

As part of the NASA Conservation of Strategic Aerospace Materials (COSAM) program [1,2], we are studying the role of cobalt on various nicke1base superalloys with the aim of reducing the consumption of this strategic element in critical aerospace applications. Superalloys (predominantly the wrought nicke1-base alloys containing between 10 and $20 \% \mathrm{Co}$ ) consume rough1y $40 \%$ of the cobalt in the United States [3].

Prior to research [4-12] spurred by the cobalt supply crisis at the end of the 1970's, much of the information concerning the role of cobalt in nicke1-base superalloys had originated in Heslop's 1964 paper [13]. He reported that a $17 \%$ cobalt addition to Nimonic $80 \mathrm{~A}$ (an early $\gamma^{\prime}$ strengthened superalloy) markedly improves the stress rupture resistance of this alloy. The Nimonic alloys developed after this cobalt containing version of Nimonic $80 \mathrm{~A}$ contain between 13 and $20 \%$ cobalt. Similarly, their American counterparts--Waspaloy, the Udimet alloys, the Rene alloys, and the Mar M alloys, for example--a11 contain from 8 to $19 \%$ cobalt [14]. The effects of cobalt on the structure and properties at service temperatures were recently studied in some detail in many of these alloys [4-12], and it was found that the role of cobalt is not as critical as believed in terms of enhancing mechanical properties in this temperature range.

Heslop [13] also noted that the hot ductility (or workability) of high strength superalloys, based on studies of Nimonic 115 type alloys, increased uniformly with alloy cobalt content. This conclusion was supported in the paper by a sketch without data points showing ductility (twists to failure on a torsion P1astometer) in the hot working temperature range increasing linearly with cobalt content. This information has been cited repeatedly as evidence for cobalt being necessary to enhance hot workability of supera1loys $[3,15,16]$ and has become part of the 'common wisdom' concerning cobalt. In this paper we report on our recent study of this issue. In so doing, we will show that wrought superalloys are workable even in the absence of cobalt. For the study we chose to concentrate on that very same Nimonic 115 alloy originally studied by Heslop. These results, and results from other alloys, are shown to be generally applicable to the high strength (high $\gamma^{\prime}$ fraction) nickel-base superalloys. Some information of the effect of hot working procedure on mechanical properties of Nimonic 115 and Udimet 700 will also be presented.

\section{Experimenta1 Procedure}

Four $68 \mathrm{~kg}$. ( $150 \mathrm{lbs}$ ) heats of alloys based on the Nimonic 115 composition with varying amounts of nickel substituted for the nominal $14 \%$ cobalt were prepared for this study. Table $I$. Also given in Table I are chemistries of alloys referred to later during discussion. Note that with the exception of the systematic nicke1/cobalt substitutions, a11 other alloy contents are constant in each of the systems studied. These alloys were vacuum induction me1ted (VIM) and cast at Special Metals Corporation of New Hartford, New York, in a $227 \mathrm{~kg}(500 \mathrm{lb}$.) capacity furnace. To refine the grains of the cast microstructure these ingots were then vacuum arc reme1ted (VAR) into $150 \mathrm{~mm}$ ( 6 inch) diameter ingots. Since these alloys were produced by and bought from Special Metals Corporation, the designation Nimonic 115 alloy should, strictly speaking, be Udimet 115 .

Primary breakdown of the cast structure in superalloys is a most difficult processing step. P1anes of weakness [17,18] are a result of the casting segregation combined with the columnar grains. This structure must 
be deformed and homogenized before shape forming (for example, hot forging) can proceed [19-22]. Simulation tests, whether they are tensile, torsion or compression, cannot reproduce the conditions in the primary deformation stage where the failure mode is predominantly edge cracking or centerline bursting [18,23]. For this reason we examined the hot workability by direct observation of hot rolled ingots. Standard mill procedures for Nimonic 115 (or Udimet 115) were followed as to the reduction per pass, and the hold times for the thermal processing steps--homogenization, overaging, and reheat between deformation passes. Initially, the standard temperatures prescribed for these processing steps were used. Modifications in these processing temperatures are discussed below.

Tab1e I. A11oy Compositions (in weight \%)

\begin{tabular}{|c|c|c|c|c|c|c|c|c|}
\hline Fleat \# & $\mathbf{N i}$ & Co & Cr & $\mathrm{T} \mathbf{i}$ & A1 & Mo & c & B \\
\hline \multicolumn{9}{|l|}{ Nimonic 115} \\
\hline$D \$-2280$ & Ba1. & 13.8 & 14.6 & 3.95 & 4.91 & 3.52 & .159 & .0165 \\
\hline D 5-2281 & Bal. & 10.0 & 14.6 & 3.87 & 4.75 & 3.50 & .164 & .0175 \\
\hline D 5-2282 & Bal. & 5.2 & 14.4 & 3.97 & 4.88 & 3.50 & .149 & .0175 \\
\hline D 5-2283 & Ba1. & $<0.2$ & 14.4 & 3.91 & 4.81 & 3.45 & .141 & .0178 \\
\hline D5-252 & Ba1. & $<0.1$ & 14.4 & 4.03 & 4.93 & 3.48 & .144 & .0183 \\
\hline D3-2521 & Bal. & 5.1 & 14.5 & 3.94 & 4.90 & 3.53 & .153 & .0177 \\
\hline D5-2522 & & 10.0 & 14.5 & 3.93 & 4.97 & 3.55 & .157 & .0180 \\
\hline D) $5-2523$ & $\mathrm{Ba} 1$. & 15.0 & 14.6 & 3.99 & 4.88 & 3.54 & .151 & .0175 \\
\hline \multicolumn{9}{|c|}{ Ud inet $700[9,10]$} \\
\hline D.5-1884 & Bal & $<0.1$ & 15.1 & 3.46 & 4.12 & 5.00 & .06 & .025 \\
\hline D)-1885 & Bal. & 4.3 & 15. & 3.5 & 4.1 & 4.90 & .07 & .024 \\
\hline D5-1886 & $\mathrm{Ba} 1$. & 8.6 & 15.0 & 3.51 & 4.05 & 5.05 & .06 & .022 \\
\hline D5-1932 & Bas. & 12.8 & 14.7 & 3.61 & 4.10 & 5.00 & .06 & .023 \\
\hline D5-1933 & Bai. & 17.0 & 14.9 & 3.60 & 4.08 & 5.03 & .06 & .028 \\
\hline D $1-3073$ & Ba1. & 0.2 & 15.0 & 3.54 & 4.00 & 4.70 & .07 & .032 \\
\hline D $1-3074$ & $\mathrm{BaI}$. & 4.9 & 14.4 & 3.57 & 4.02 & 4.77 & .06 & .030 \\
\hline \multicolumn{9}{|c|}{ Od inet $720 \quad[5,25]$} \\
\hline D5-2284 & Ba1. & 14.8 & 17.9 & 4.95 & 2.46 & 3.09 & .037 & .031 \\
\hline D 3-2285 & Bal. & 7.5 & 17.8 & 5.03 & 2.52 & 3.11 & .031 & .031 \\
\hline D5-2286 & Ba1. & $<0.2$ & 17.6 & 4.99 & 2.48 & 3.04 & .036 & .030 \\
\hline & A11 Ddimet & 720 & a 11 oy s & contain & $1.2 \% \mathrm{~W}$ & & & \\
\hline \multicolumn{9}{|l|}{ IN 738 [25] } \\
\hline D $1-2944$ & Ba1. & 8.4 & 16. & 3.37 & 3.46 & 1.64 & .096 & .008 \\
\hline D $1-2945$ & Bal. & 0.4 & 16.1 & 3.33 & 3.47 & 1.62 & .097 & .009 \\
\hline \multirow[t]{2}{*}{ D: $1-2946$} & Ba1. & 4.2 & 16.1 & 3.35 & 3.49 & 1.64 & .095 & .008 \\
\hline & A11 IN 738 & 3110 & oys cont & of is $2.4 \%$ & $6,1.6 x$ & * Ta, & and $0.74 \%$ & $\mathrm{Nb}$ \\
\hline
\end{tabular}

For a 11 alloys: $\mathrm{Fe}<0.18 \%, \mathrm{~S}<.003 \%, \mathrm{P}<.005 \%, 0, \mathrm{~N}<12 \mathrm{ppm}$

Following standard practice for pre-rolling treatments, the VIM/VAR ingots were homogenized for 24 hours at $1204^{\circ} \mathrm{C}\left(2200^{\circ} \mathrm{F}\right)$. After a furnace cool, the al1oys were overaged for 10 hours at $1107^{\circ} \mathrm{C}\left(2025^{\circ} \mathrm{F}\right)$ to precipitate and coarsen a small fraction of the $\gamma^{\prime}$ phase. These precipitates pin grain boundaries to prevent abnormal growth during hot working. The ingot surfaces were ground to remove any defects and then the ingots were sealed in $6 \mathrm{~mm}(1 / 4 \mathrm{inch})$ thick mild steel cans to prevent surface chilling during ro11ing.

The canned ingots were rol1ed at $1093^{\circ} \mathrm{C}\left(2000^{\circ} \mathrm{F}\right)$ to a final target of $19 \mathrm{~mm}$ ( $3 / 4 \mathrm{inch})$ round rods. The standard procedure for this material calls for squaring passes until the ingot is reduced to a roughly $40 \mathrm{~mm}(1.6$ inch) round corner square (RCS) bar. The reheating time between passes was 30 minutes to equillibrate the piece to the rolling temperature. The steel jacket was then removed from the piece and it was rolled to $20 \mathrm{~mm}$ (.8 inch) RCS bar. The finishing passes first reduce the bar to an oblong cross section $15 \times 25 \mathrm{~mm}$ and then to the final $19 \mathrm{~mm}$ round. During these operations the reheat times were reduced to 15 minutes since the smaller cross sections equilibrate more rapidy. Sections of the low cobalt alloys were also over- 
aged and ro11ed at $1176^{\circ} \mathrm{C}\left(2150^{\circ} \mathrm{F}\right)$ into $13 \times 62 \mathrm{~mm}(0.5 \times 2.5$ inch $)$ p1ate, see below for details on these rolling experiments.

Optical and SEM metallography were used to characterize the material at the various stages of processing (i.e.. after casting, homogenizing, overaging and hot working). Particular attention was paid to the chemistry and morphology of the carbides after each step of thermal mechanical processing. The SEM specimens were electropolished in a $20 \% \mathrm{H}_{2} \mathrm{SO}_{4}$-methanol solution. These specimens were then etched in either a $10 \%$ HCi-methanol solution to reveal the carbide structure or an aqueous $1 \%\left(\mathrm{NH}_{4}\right)_{2} \mathrm{SO}_{4}-1 \%$ citric acid solution to reveal the $\gamma^{\prime}$ structure. With these etchants the carbides are distinguished by appearance in the SEM. MC carbides appear chunky and are uniformly dispersed and the $M_{23} C_{6}$ carbides are found only at heterogeneities (particularly the grain boundaries). The chemistry of the carbides were also determined nsing an energy dispersive $X$-ray analysis (EDS) unit in a JEOL JEM-100CX analytical electron microscope. In these alloys carbides with high chromium content are $\mathrm{Cr}_{23} \mathrm{C}_{6}$ type and carbides with high titanium content are Tic type, as confirmed by X-ray diffraction of extracted carbides [24].

The $\gamma^{\prime}$ solvus of each composition was determined using a Perkin-Elmer Differential Thermal Analyzer (DTA) with a temperature accuracy of approximately $5^{\circ} \mathrm{C}$. The $\mathrm{Cr}_{23} \mathrm{C}_{6}$ carbide solvus for each alloy composition was determined metallographically on homogenized cast material aged for 24 hours at various temperatures followed by a water quench, see next section for details on this characterization.

\section{Resnits and Discussion}

Removing cobalt from Nimonic 115 causes a drastic reduction of the primary workability at the standard rolling temperature of $1093^{\circ} \mathrm{C}\left(2000^{\circ} \mathrm{F}\right)$. The alloys with 0 and $5 \%$ cobalt failed during the initial rolling pass after a reduction in area of less than $10 \%$, Fig. 1. In contrast, the alloys containing 10 and $14 \%$ (nominal Nimonic 115) cobalt were successfully rolled to the targeted $19 \mathrm{~mm}(3 / 4 \mathrm{inch})$ rods--a total reduction in area of greater than 98\%. The reduced cobalt alloys fractured in a brittle manner when rolled at the standard hot working temperature. The microstructure of these materials, seen in Fig. 2, includes $\mathrm{Cr}_{23} \mathrm{C}_{6}$ carbides forming a continuous network at the grain boundaries. Fracture analysis shows that the cracks propagate along these intergranular carbides, Fig. 3.

In Udimet $700[9,10]$ and $0 d$ imet $720[5,25]$, we found that reducing the cobalt content a1so resulted in the formation of stringers of $\gamma^{\prime}$ and carbides or borides, Fig. 4. Althongh these alloys were rolled successfully (since these alloys contain less carbon and therefore fewer stringers), the resulting wrought structures interfered with heat treatment for optimal properties. Cobalt-free Udimet 700 , after a full solution treatment (used in creep resistant applications such as turbine blades), was at least equal to the standard alloy in tensile, creep and stress rupture strengths $[9,10]$. However, the same alloy did not respond to the standard sub-solvus heat treatment used for lower temperature disk applications where fatigue resistance and tensile strength require a finer grain size. The $\gamma^{\prime}$ incorporated in the stringers was unavailable for its critical role as a dispersed particle strengthener. The low cobalt alloys had effectively 1 ess $\gamma^{\prime}$ and thexefore lower strength. The stress rupture resistance of Udimet $700[9,10]$ after standard thermomechanical processing (TMP) dramatically shows this effect, lower curve in Fig. 5. Low cobalt Udimet 720 [5,25] could not be heat treated--the stringers would not dissolve below the incipient me1ting point. 


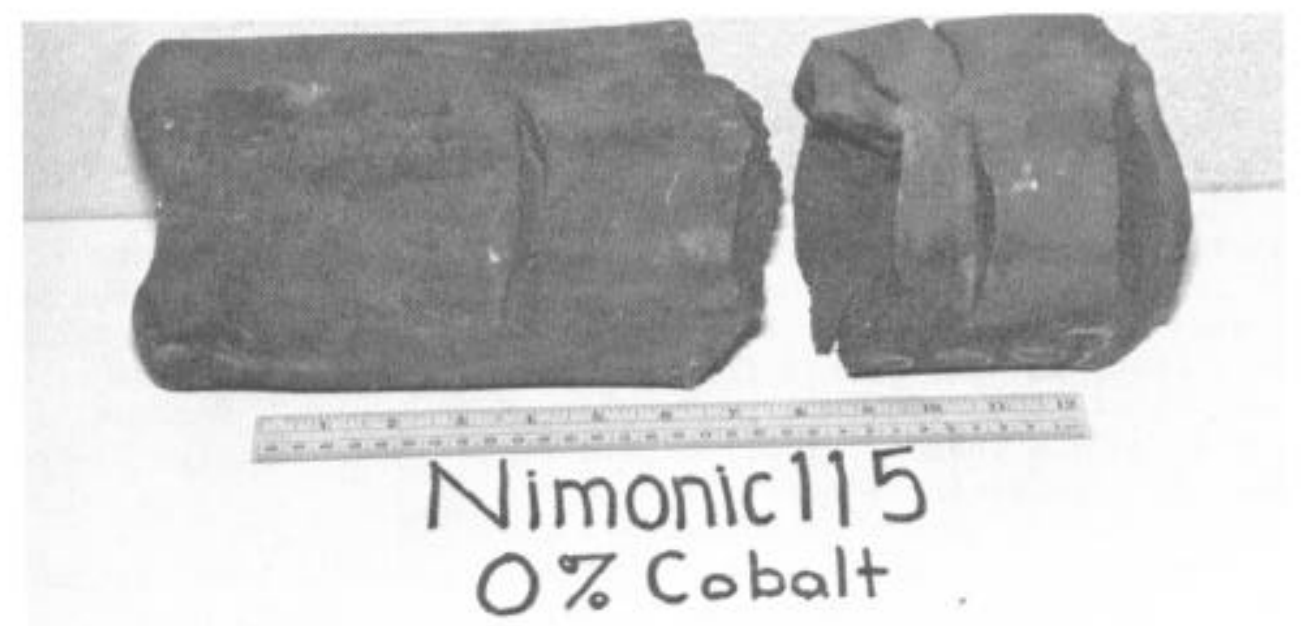

Fig. 1. A11oy D5-2283 with $0 \%$ cobalt after attempting to hot rol1 the alloy using the standard procedure for Nimonic 115 .

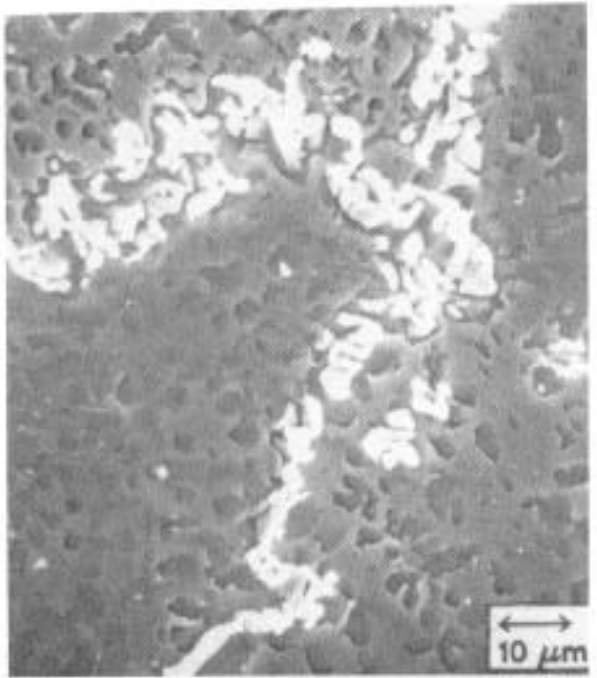

Fig. 2. SEM micrograph showing the continuous grain boundary carbides in the alloy in Fig. 1 .

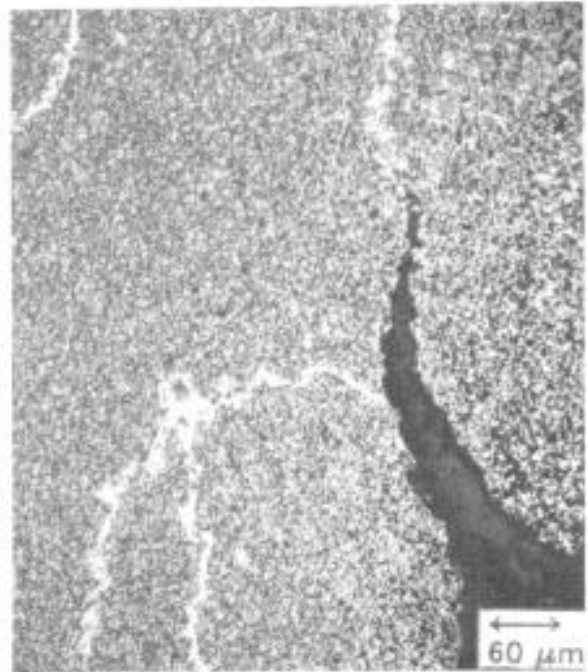

Fig. 3. Micrograph of secondary cracks near the fracture surface in the $0 \% \mathrm{Co}$ s11 oy in Fig. 1 .
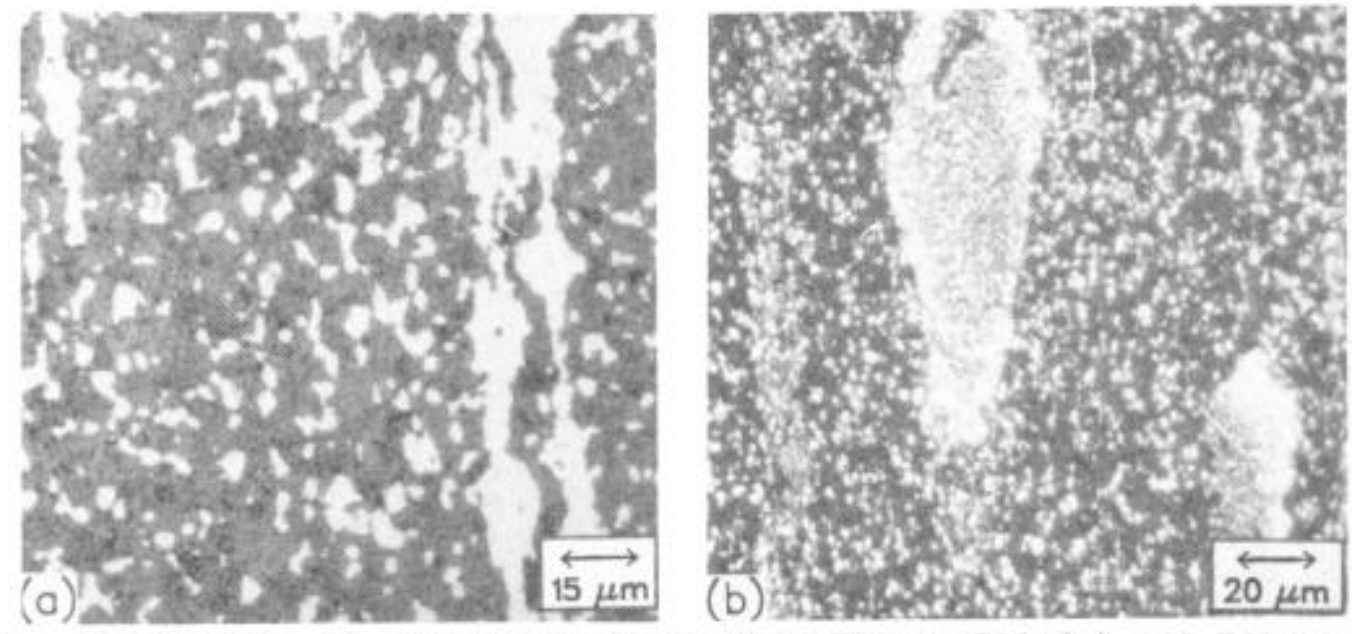

Fig. 4. Micrographs of stringers cobalt-free Udimet 700 (a) and Udimet 720 (b) resulting from using standard processing temperatures. 
Since both the $\mathrm{TiC}$ and the $\mathrm{Cr}_{23} \mathrm{C}_{6}$ carbides contain only traces of coba1t [24], it is unlikely that cobalt directly affects the stability of those carbides. However, cobalt has been shown to affect the $\gamma^{\prime}$ solvas of nicke1-base superalloys [3-14], and it therefore may affect the solvus between $\mathrm{Cr}_{23} \mathrm{C}_{6}$ and $\mathrm{TiC}$ carbides by altering the activities in the $\gamma$ matrix of such carbide and $\gamma^{\prime}$ forming elements as titanium. Differential thermal analysis (DTA) on the alloys reveals that removing cobalt indeed increases the $\gamma^{\prime}$ solvus of the Nimonic 115 type alloys from $1178^{\circ} \mathrm{C}$ in the standard alloy to $1228^{\circ} \mathrm{C}$ in the cobalt-free version, see Fig. 6. This effect also occurs in Udimet 700, Udimet 720, IN 738, MERL 76, and MarM 247 [5-12] so the results of the current study on Nimonic 115 may perhaps be generally applicable to high strength superalloys.

To determine the precipitating carbide solvus and simulate the thermal processing prior to deformation, cast material from each of the four Nimonic 115 heats were solutioned now at $1240^{\circ} \mathrm{C}\left(2264^{\circ} \mathrm{F}\right)$ and overaged at various lower temperatures for 24 hours. The cast microstructures are similar except that a quantity of very fine $\mathrm{Cr}_{23} \mathrm{C}_{6}$ carbides had precipitated in the 0 and $5.2 \%$ cobalt alloys during cooling, Fig. 7. Homogenizing the alloys at $1240^{\circ} \mathrm{C}$ dissolves these carbides so the microstructures of a11 four alloys were very similar at this point--all $\gamma^{\prime}$ is solutioned and the only precipitates are the primary TiC carbides and a few borides, Fig. 7 , center.

During next processing step, overaging at $1107^{\circ} \mathrm{C}\left(2025^{\circ} \mathrm{F}\right)$, the carbide stringers form in the low cobalt alloys bnt not in standard Nimonic 115, see Fig. 7. In the standard a11oy, only a small amount of discrete $\gamma^{\prime}$ and TiC particles are found at the grain boundaries. However, in the cobalt-free alloy (and similarly the alloy with $5.2 \%$ cobalt) a continuous film of precipitated $\mathrm{Cr}_{23} \mathrm{C}_{6}$ is the striking microstructural feature. Microstructures of the cobalt-free alloy at the modified overaging temperatures chosen for ro11ing are shown in Fig. 8. Note the marked similarity of the cobalt-free alloy overaged at $1175^{\circ} \mathrm{C}$ and the standard a11oy overaged at $1107^{\circ} \mathrm{C}$. Overaging at $1150^{\circ} \mathrm{C}$ produces a very coarse precipitation of the carbides at various locations within the cobalt-free alloy. These heavy precipitates are not continuous, indicating that $1150^{\circ} \mathrm{C}$ is very near the carbide solvus temperature-it may be above or below depending on local chemistry.

This $\mathrm{Cr}_{23} \mathrm{C}_{6}$ solvus as a function of cobalt content in the homogenized cast alloys, as determined metallographica11y, is included in Fig. 6 . Note that this carbide solvos follows the same trend as the $\gamma^{\prime}$ solvus and, again, that the pre-ro11ing overage temperature $1107^{\circ} \mathrm{C}\left(2025^{\circ} \mathrm{F}\right)$ is above the $\mathrm{Cr}_{23} \mathrm{C}_{6}$ carbide solvus for the alloys with greater than $10 \%$ cobalt and is below the solvus for the alloys with lower cobalt contents. Not surprisingly, the 10 and $14 \%$ cobalt containing alloys rolled successfully and the alloys containing 5.2 and $0 \%$ cobalt did not. Conversely, the hot workability of the 1 ow cobalt alloys should be enhanced if the overage and rolling temperatures are raised above the $\mathrm{Cr}_{23} \mathrm{C}_{6}$ solvus in Fig. 6 .

This premise was confirmed experimenta11y by removing a $50 \times 50 \times 100 \mathrm{~mm}$ ( $2 \times 2 \times 4$ inch) section of the piece shown in Fig. 1 and a similar section of the $5.2 \%$ cobalt alloy and attempting to re-work this material. Since the $\mathrm{M}_{23} \mathrm{C}_{6}$ carbide reaction is generally reversible in superalloys, the two sections were homogenized for 24 hours at $1204^{\circ} \mathrm{C}\left(2200^{\circ} \mathrm{F}\right)$ to dissolve these carbides and overaged at $1177^{\circ} \mathrm{C}$. Both the 0 and the $5.2 \%$ cobalt a11oys were successful1y rol1ed at $1177^{\circ} \mathrm{C}$ to $13 \mathrm{~mm}(1 / 2$ inch) thick p1ates after this thermal treatment.

Similar alloys (D5-2520 and D5-2521 in Table I) were homogenized at $1204^{\circ} \mathrm{C}$, overaged at $1163^{\circ} \mathrm{C}\left(2125^{\circ} \mathrm{F}\right)$, and rolled at $1149^{\circ} \mathrm{C}\left(2100^{\circ} \mathrm{F}\right)$ in the 


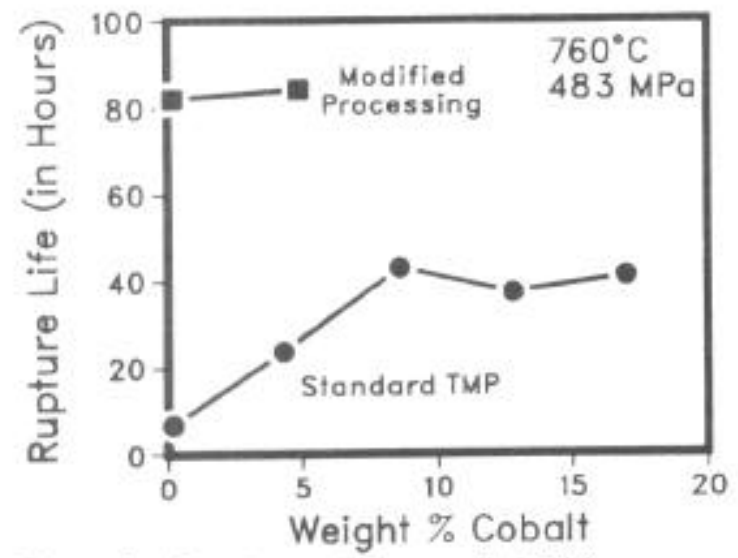

Fig. 5. Rupture 1 ives of 0700 as a function of cobalt content at $760 \mathrm{C}$ and $483 \mathrm{MPa}$.

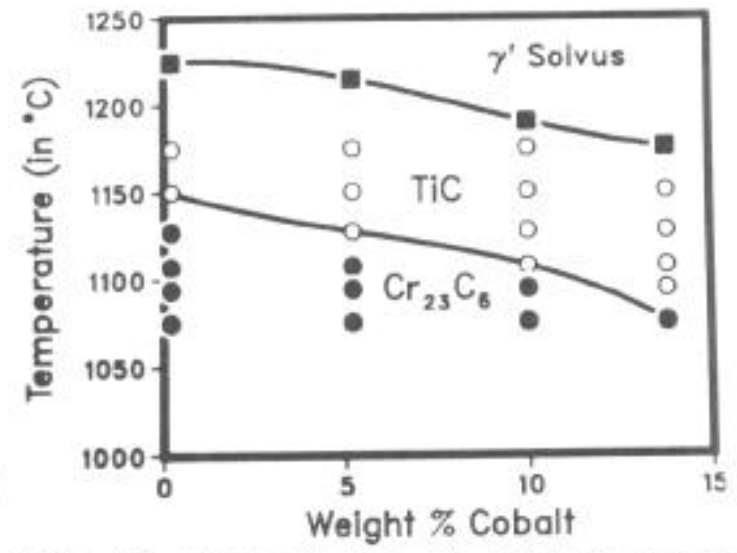

Fig. 6. Plot of the $\gamma^{\prime}$ solvus and the carbide transformation temperatures in N115 as a function of cobalt content.

$14 \%$ Co
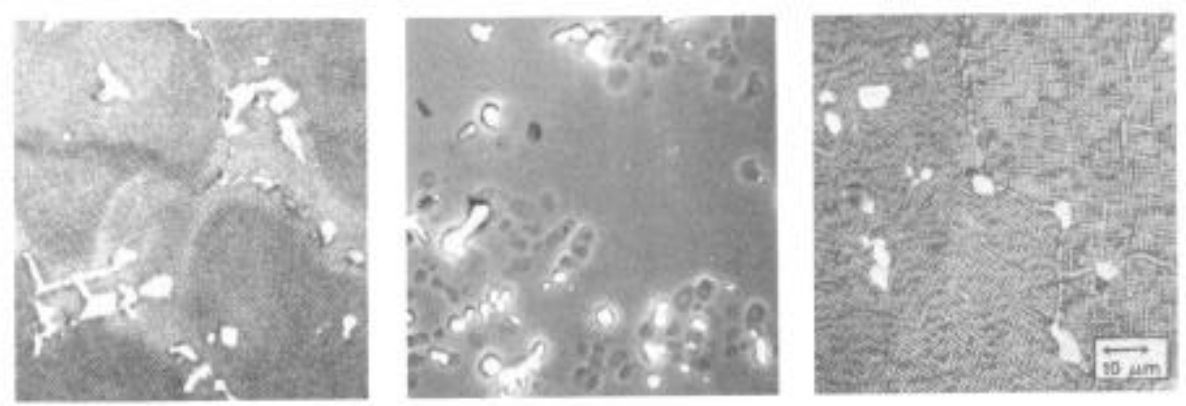

$0 \% \mathrm{Co}$

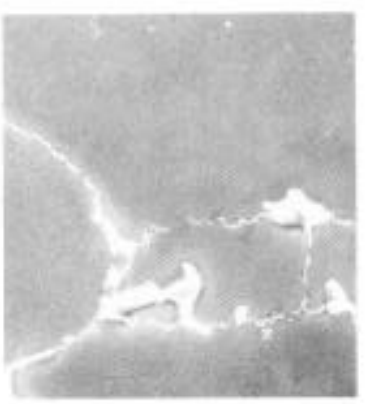

As Cast

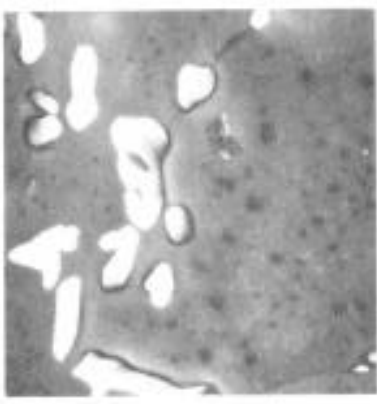

Homogenization at $1240^{\circ} \mathrm{C}$

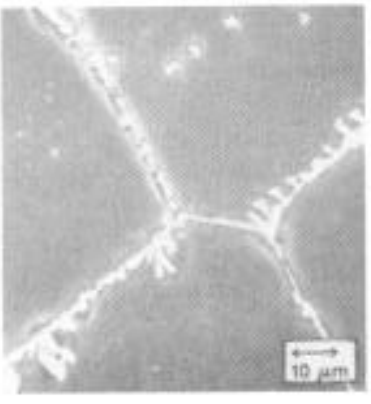

$+1107^{\circ} \mathrm{C}$ Overage

Fig. 7. SEM micrographs of the microstructures in standard N115 (top) and and the cobalt-free alloy (bottom) formed during thermal treatments prior to hot working.

$1150^{\circ} \mathrm{C}$ Overage

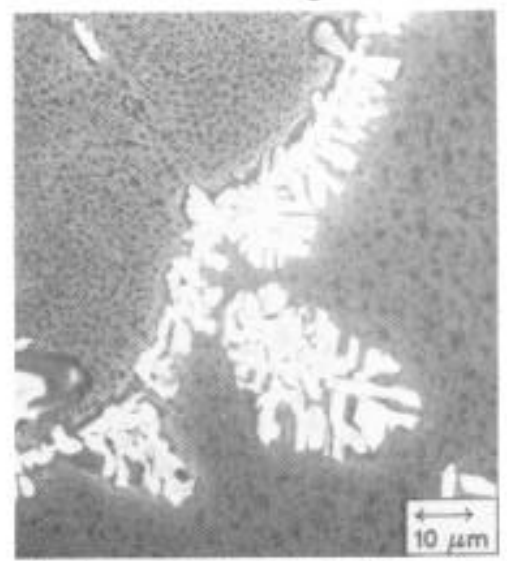

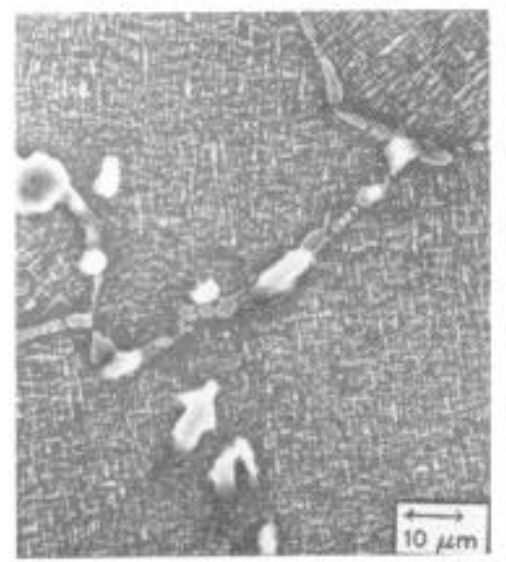

$1175^{\circ} \mathrm{C}$

Overage

Fig. 8. Cobalt-free Nimonic 115 overaged at $1150^{\circ} \mathrm{C}$ and $1175^{\circ} \mathrm{C}$. Note that the discontinuous carbide precipitates formed at $1150^{\circ} \mathrm{C}$ are absent at $1175^{\circ} \mathrm{C}$. 
production mill at Special Meta1s Corporation. The a11oy with 5\% coba1t (D5-2521) was successfu11y worked from the $150 \mathrm{~mm}$ (6 inch) VAR ingot to 19 mm bar with very little reconditioning with a yield that was at least as much as the standard alloy (D5-2523). Conditioning losses for the cobaltfree alloy were high (sections with a good deal of surface cracking must be removed). In order to reduce any material successfully from the $22 \mathrm{~mm}$ RCS to $19 \mathrm{~mm}$ round bar, the rolling temperature was raised to $1177^{\circ} \mathrm{C}\left(2150^{\circ} \mathrm{F}\right)$. The resulting microstructure in this alloy suffers from the same deficiency of strengthening $\gamma^{\prime}$ as Udimet 700 in our earlier study [10] and its mechanical properties decrease according1y, Fig. 9.

Micrographs of the cobalt-free and the standard Nimonic 115 wrought alloys are shown in Fig. 10. Only slight differences in the $\gamma^{\prime}$ and in the grain sizes distinguish the standard alloy worked at $1094^{\circ} \mathrm{C}$ from the cobaltfree version overaged and worked at $1177^{\circ} \mathrm{C}$. (Compare to the stringered microstructure of the cobalt-free alloy worked at $1149^{\circ} \mathrm{C}$. ) The fine grain size and $\gamma^{\prime}$ distribution in the materials in Figs. 10a and 10b are typical of extruded or rolled billet. Material with this structure is amenable to additional working or heat treatment. These wrought alloys were successfully heat treated with the solution temperature also adjusted to the increased $\gamma^{\prime}$ solvus of the low cobalt alloys. The mechanical properties of these alloys are also shown in Fig. 9, indicating that the effects of cobalt can be removed with proper thermo-mechanical processing.

To further test the effect of the transformation temperatures (or coba1t content) on the thermo-mechanical processing, we worked two low cobalt heats of Udimet 700 [25] at temperatures prescribed by its $\gamma^{\prime}$ and carbide solvi. The standard practice temperatures used in this study for Udimet 700 cal1 for homogenization at $1177^{\circ} \mathrm{C}\left(2150^{\circ} \mathrm{F}\right)$, overaging at $1107^{\circ} \mathrm{C}\left(2025^{\circ} \mathrm{F}\right)$ and ro11ing at $1094^{\circ} \mathrm{C}\left(2000^{\circ} \mathrm{F}\right)$. Heat D1-3073 (0\% Co) was homogenized at $1204^{\circ} \mathrm{C}$ $\left(2200^{\circ} \mathrm{F}\right)$, overaged at $1163^{\circ} \mathrm{C}\left(2125^{\circ} \mathrm{F}\right)$, and rolled at $1149^{\circ} \mathrm{C}\left(2100^{\circ} \mathrm{F}\right)$. For heat $01-3074(5 \% \mathrm{Co})$ the temperatures were, respective1y, 1191,1149 , and $1135^{\circ} \mathrm{C}\left(2175,2100\right.$, and $\left.2075^{\circ} \mathrm{F}\right)$. The resulting wrought microstructures did not contain the stringers and were marked1y similar to the standard alloy, Fig. 11. Not surprising $1 y$, the stress rupture resistance of these alloys (often cited as the mechanical property most sensitive to cobalt content) improved substantially, see top curve in Fig. 5 .

It may be fortuitous that both these reduced cobalt alloys exceed the stress rupture resistance of the standard alloy. However, the results clearly demonstrate that the strategic element, cobalt, is not an essential alloying element in the alloy Udimet 700 . The invariance in the properties of Nimonic 115 with cobalt content indicates that the cobalt currently used in this whole class of alloys may be unnecessary and possibly detrimental (as in the case of oxidation and hot corrosion resistance [5]).

We emphasize the importance of the phase transformation temperatures in and around the hot working temperatures of nicke1-base superalloys. In this study we used cobalt as a means of altering these temperatures without intrinsically affecting the alloy. Cobalt's effect on the $\gamma^{\prime}$ solvus has been known for some time--it can be seen directly from the ternary Ni-A1-Co phase diagram and pseudo-binary Ni-A1 diagrams $[9,13,26]$. Cobalt does not form a $\mathrm{Co}_{3} \mathrm{Al}$ phase equivalent to $\mathrm{Ni}_{3} \mathrm{Al}$, so its presence in $\gamma^{\prime}$ would be expected to de-stabilize (or lower the solvus of) that phase. We believe a better understanding of the effect of cobalt (and the $\gamma^{\prime}$ solvus) on the carbide phases of superalloys has developed from this study. Consequently, this understanding resulted in the redesign in of TMP procedures which enhanced the workability and improved the mechanical properties of low or no cobalt superalloys. 

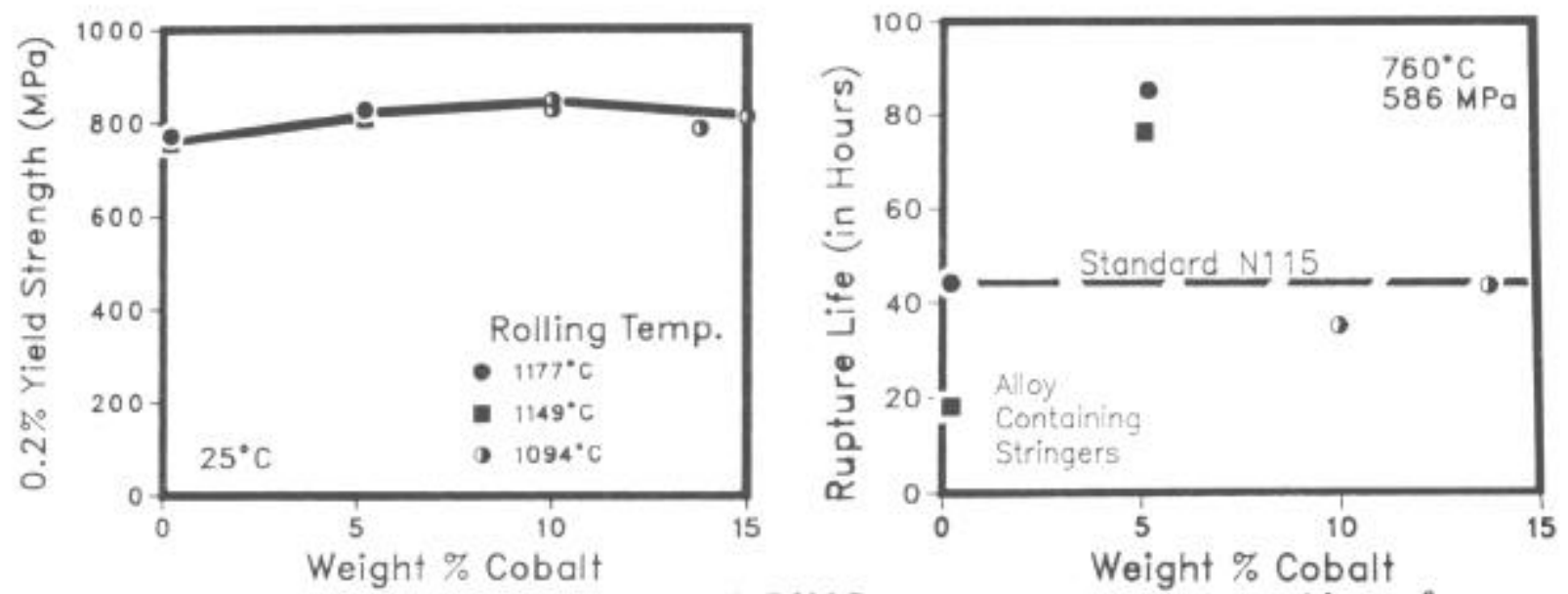

Fig. 9. Room temperature tensile and $760^{\circ} \mathrm{C}$ stress rupture properties of Nimonic 115 as a function of cobalt content. Notice the difference in rupture 1 ives of the $0 \% \mathrm{Co}$ alloy when worked at $1177^{\circ} \mathrm{C}$ compared with the same cobalt content alloy worked at $1149^{\circ} \mathrm{C}$.
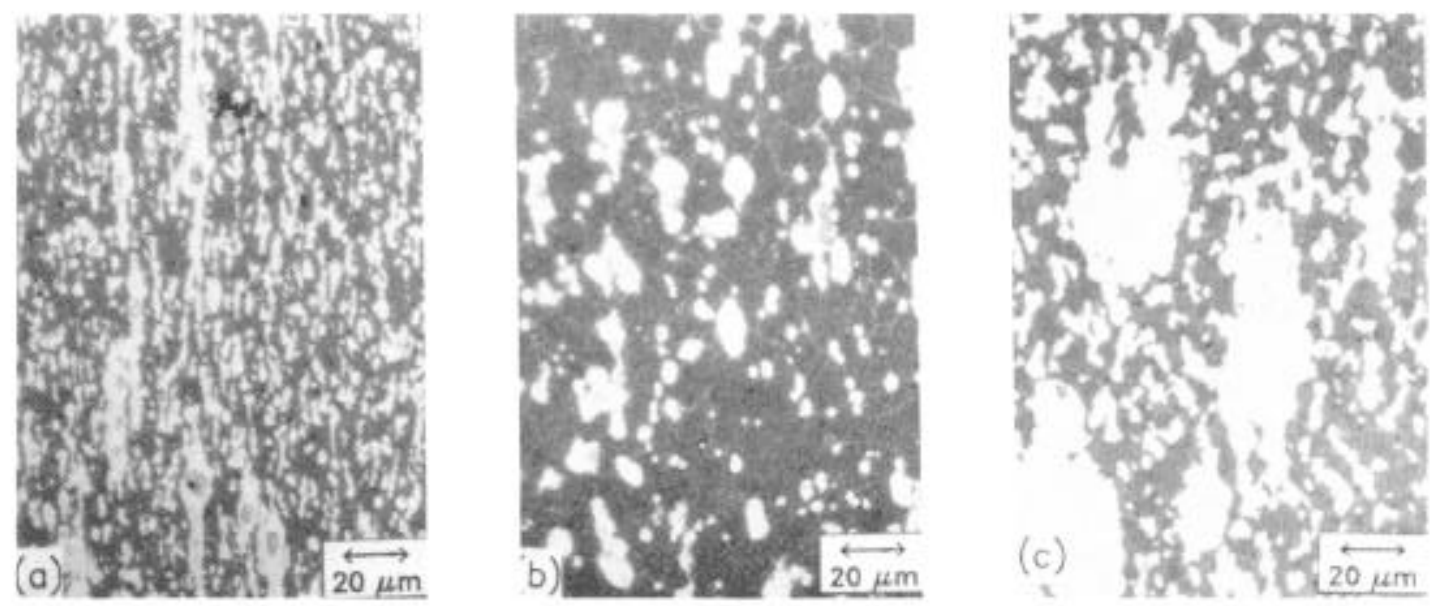

Fig. 10, Optical micrographs of as rolled Nimonic 115: (a) the standard a11oy worked at $1094^{\circ} \mathrm{C}$, (b) the cobalt-free alloy worked at $1177^{\circ} \mathrm{C}$ and (c) worked at $1149^{\circ} \mathrm{C}$. The $1 \mathrm{ight}$ areas in the micrographs are $\gamma^{\prime}$ and the large 1 ight areas in (c) are the $\gamma^{\prime} /$ carbide stringers.
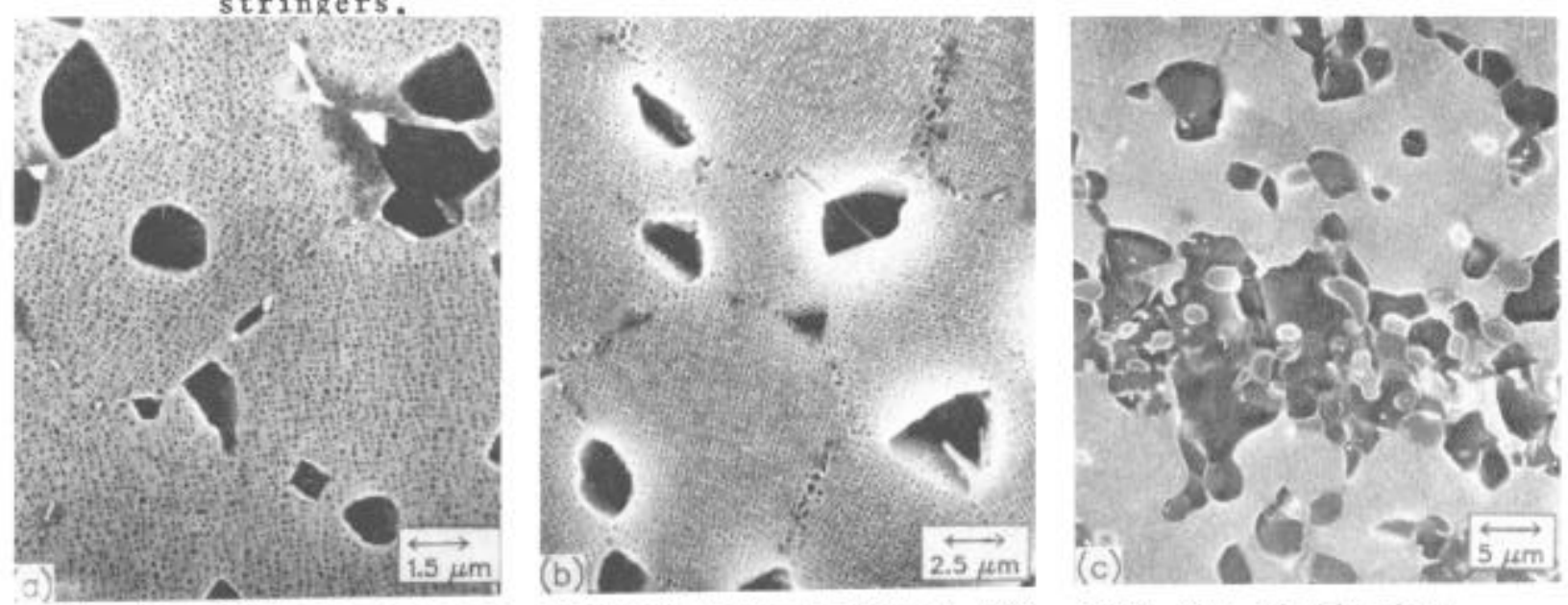

Fig. 11. SEM micrographs of heat treated Ddimet 700. Note the similarity between the microstructure of the standard alloy (a) worked at $1094^{\circ} \mathrm{C}$ and the cobalt-free a 11 oy (b) worked at $1149^{\circ} \mathrm{C}$. In contrast is the cobalt-free alloy worked at $1094^{\circ} \mathrm{C}$ (c) filled with stringers of $\gamma^{\prime}$ and carbides. 
Finally, this link between the $\gamma^{\prime}$ solvus and the transition or solvus temperature between the TiC and the $\mathrm{Cr}_{\mathbf{2}_{3}} \mathrm{C}_{6}$ carbides can be easily rationalized. The $\gamma^{\prime}$ phase with its $\mathrm{Ni}_{3}$ (A1, Ti) base composition competes with the TiC carbide for titanium. Gamma prime precipitation results in the $\gamma$ matrix being depleted of titanium and enriched with chromium, which is rejected by the $\gamma^{\prime}[10,27,28]$, thas favoring the reaction

$$
\frac{23}{6}[\mathrm{Cr}]+\mathrm{TiC} \longrightarrow \frac{1}{6} \mathrm{Cr}_{23} \mathrm{C}_{6}+[\mathrm{Ti}]
$$

where [X] represents element $X$ in solution in the $\gamma$ matrix. Such an explanation is consistent with the results of Collins [29] showing the transformation of MC carbides to $M_{23} C_{6}$ at temperatures below the $\gamma^{\prime}$ solvus for a for a range of alloys. The connection between the $\gamma^{\prime}$ solvus and TiC/ $\mathrm{Cr}_{23} \mathrm{C}_{6}$ transformation temperature is then due to the temperature dependence of the relative titanium and chromium activities. Cobalt is not a component of either type of carbide and it is only a minor component of $\gamma^{\prime}$. However, it does affect the $\gamma^{\prime}$ solvus, and hence, the activity of titanium and chromium in the matrix resulting in the temperature dependence of the carbide solvus. For this reason a high $\gamma^{\prime}$ solvus would result in the $\mathrm{Cr}_{23} \mathrm{C}_{6}$ being stable to higher temperatures in the low cobalt alloys.

\section{Concluding Remarks}

The effects of cobalt on the hot workability of Nimonic 115 can be summarized as follows:

1) Cobalt lowers the $\gamma^{\prime}$ solvus, which in turn, 1 owers the $\mathrm{Cr}_{23} \mathrm{C}_{6}$ carbide solvus.

2) The hot working range is bracketed by these transformation temperatures, since below the $\mathrm{Cr}_{23} \mathrm{C}_{6}$ solvus, brittle carbide networks deleteriously affect workability and above the $\gamma^{\prime}$ solvus abnormal grain growth can occur. This conclusion may be generally applicable to superalloys.

3) According1y, removing cobalt from Nimonic 115 (or similar a1loy) necessitates an increase in the hot working temperature of the alloy in order to recover hot workability.

4) The mechanical property losses in this a11oy and in Udimet 700 with the reduction of cobalt are shown to result from the change in the carbide transformation temperature and can be remedied with the self-same changes in processing temperatures which had restored the lost workability.

We emphasize that similar studies on the wrought alloys Udimet 700 $[5,25]$ and Udimet 720 [25] also show that both $\gamma^{\prime}$ solvus and the stringered carbide solvus temperatures appear to increase as cobalt is removed from the alloy. In cobalt-free versions of these alloys, the stringers resulted in complications in the normal heat treatment which were remedied with the appropriate thermomechanical processing. According1y, contrary to popular belief, cobalt is not essential for hot workability nor is it essential for mechanical strength.

An interesting a1ternative to the application of these results may be as a possible expensive powder metallurgy route for processing high 
strength turbine disk alloys. The current P/M alloys--Astroloy, IN 100, MERL 76, Rene 95 and AF 115--a11 contain between 15 and $20 \%$ cobalt and as ingots are currently too strong to conventionally hot work just below their $\gamma^{\prime}$ solvi. Based on our results, it is fair to assume that removing cobalt would raise the $\gamma^{\prime}$ solvus in these alloys rough $1 y 50^{\circ} \mathrm{C}$. This may corresponding $1 \mathrm{y}$ a11ow for the hot working of these alloys at higher temperatures, but still below their new $\gamma^{\prime}$ solvi, where the alloys would be more deformable.

A preliminary study of this proposal on a small (14 kg.) heat of IN 738, Table $I$, showed that rough1y a $40 \%$ reduction in the peak rolling resistance (a function of hot working flow stress) resulted from the $55^{\circ} \mathrm{C}$ increase in working temperature a1lowed by the removal of the cobalt from the standard alloy containing 8.5\% cobalt, Fig. 12. These stresses are calculated from the current drawn by a constant speed rolling mill and the strains are determined by the reduction per pass. This and other work on the hot workability of ingots of a cobalt-free MERL-76 type superalloy is in progress.

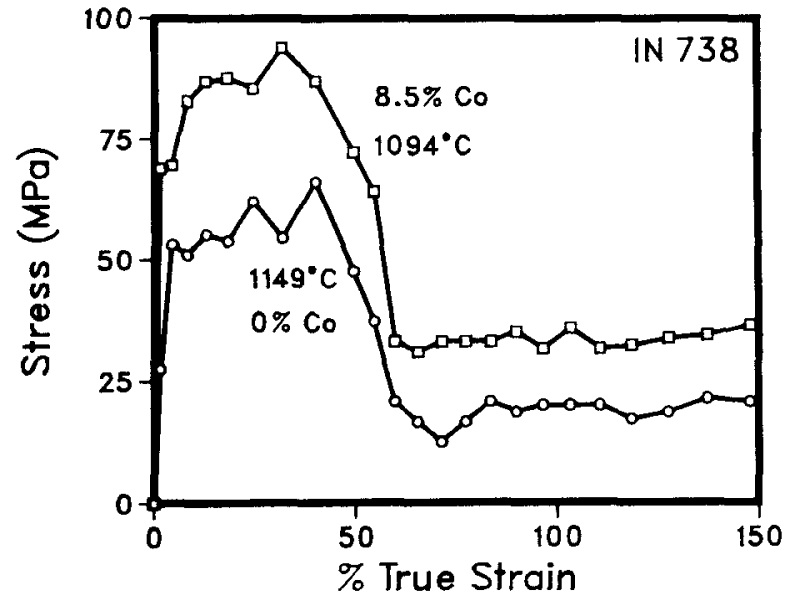

Fig. 12. Plot of the resistance to ro11ing of IN 738 [25].

\section{Acknow1edgements}

This study was sponsored by NASA-Lewis Research Center (Grant NAG 3-57). We thank the project monitors, Joseph R. Stephens and Coulson Scheuermann. We especially thank Tom Dresse1, Frank Sczerzenie, John Domingue, and Gern E. Marer of Special Metals Corporation for their assistance in manufacturing and processing the alloys. We also thank Cory Weinbel and Mike Casey for their contributions to this study and interesting discussions. Waspaloy and MERL, Udimet, MarM, Rene, IN and Nimonic are trademarks or designations of United Technologies Corporation, Special Metals Corporation, Martin-Marietta Corporation, the General Electric Company, the International Nicke1 Company and Henry Wiggin and Co., Ltd., respective1y.

\section{$\underline{\text { References }}$}

1. J.R. Stephens, NASA's Activities in the Conservation of Strategic Aerospace Materials, NASA Tech. Mem. \#81617, 1980.

2. J.R. Stephens, NASA Tech. Mem. \#82852, 1982.

3. J.K. Tien, et al., Journal of Metals, vo1, 32 (1980), pp. 12-20.

4. R.N. Jarrett, L. Chen and J.K. Tien, NASA Tech. Mem, to be pub1ished.

5. COSAM Program Overview, NASA Tech. Mem. \#83006, ed. by J.R. Stephens, NASA Lewis Research Center, Cleveland, 1983.

6. NBS IR \#82-2495, ed. A.G. Gray, NBS, Washington, D.C., 1982.

7. M.V. Nathal, et al., Met. Trans. A, vol 13A (1983), pp. 1767-1774.

8. M.V. Natha1, et a1., ibid., (1983), pp. 1775-1783.

9. J.K. Tien and R.N. Jarrett, in High Temperature Alloys for Gas Turbincs eds. R.Brunetaud, et a1., D. Reide1 Co.. Dortrecht, 1982, pp. 423-446.

10. R.N. Jarrett and J.K. Tien, Met. Trans. A, vo1. 13A (1982), pp. 1021.

11. G.E. Maurer, et a1., in Supera1loys 1980 , eds. J.K. Tien, et a1., ASM, Metals Park, 1980, pp. 43-52. 
12. C.C. Law, et a1., U.S.A.F Report \#AFOSR-81-0554, 1981.

13. J. Heslop, Coba1t, vo1. 24 (1964), pp. 128-137.

14. High Temperature, High Strength Nicke1-Base Alloys, 3rd Ed ., INCO,1977.

15. D. Contsouradis and L. Habraken, J.0.M., vo1. 35 (1983), pp. 40-47.

16. L. Habraken and D. Coutsouradis, Coba1t, no. 26 (1965), pp. 1-15.

17. A.J. DeRidder and R.W. Kocks, Meta1s Eng. Quarter1y, Angust, 1965.

18. H.J. McQueen and J.J. Jonas, in Meta1 Forming: Interrelation Between Theory and Practice, ed. by A.L. Hoffmanner, P1enum Press, New York, 1971, pp. 393-428.

19. J.E. Coynes, in Forgings and Properties of Aerospace Materia1s, The Metals Society, Cameron Press, London, 1978, pp. 234-247.

20. N.A. Wilkenson, ibid., pp. 35-63.

21. J.E. Coynes and W.I. Couts, Jr., in High Temperature Alloys of Gas Turbines 1982, pp. 839-852.

22. S. Fulop and H.J. McQueen, in Supera1loys-Processing, MCIC Report $\# 72-10,1972$, paper $H$.

23. R.S. Cremisco and H.J. McQueen, ibid.. paper G.

24. J.F. Radavich and M. Enge1, in NASA Tech. Mem. \#83006, 1983, pp.51-62.

25. J.K. Tien and R.N. Jarrett, unpublished research, Columbia U., 1984.

26. J. Schramm, Z. Meta11, vo1.33 (1941), p.403.

27. 0.H. Kriege and J.M. Baris, Trans. ASM, vo1. 62 (1969), pp. 195-200.

28. E.H. Van der Molen, Met. Trans., vo1. 2 (1971), pp. 1627-1633.

29. H.E. Collins, Trans. ASM, vo1. 62, 1969, pp. 82-104. 